\title{
Analysis of How to Improve the Effectiveness of Ideological and Political Courses Teaching in Higher Schools in the New Period
}

\author{
Qian Zan \\ Xi'an Medical College, Xi'an 710021, Shaanxi, China
}

Keywords: The new period; Ideological and political courses; Teaching; Effectiveness

\begin{abstract}
In the new era, with the constant deepening of the new curriculum reform, the ideological and political courses in higher schools have undergone corresponding reform, in particular, the effectiveness of the ideological and political courses should be improved. However, most of the higher schools still adopt the traditional teaching mode, and did not obtain the ideal teaching efficiency. Thus it can be seen that, in order to improve the teaching efficiency of the ideological and political courses, all kinds of reasonable and effective methods should be adopted. Based on this, this paper focuses on the analysis of how to improve the effectiveness of ideological and political courses teaching in higher schools in the new era.
\end{abstract}

\section{Introduction}

Generally speaking, since the implementation of quality-oriented education, the ideological and political courses teaching has obtained good results, and occupied a vital position in the process of carrying out quality-oriented education, which is conducive to propagating the tenet and policies of our party to students, integrating healthy ideology and culture into students' ideology, guiding students to form correct outlook on life, world outlook and values, and thus cultivating qualified talents for socialist construction. However, there are still many problems in the process of ideological and political courses teaching. Therefore, this paper analyzes how to improve the effectiveness of ideological and political courses teaching in the new era.

\section{Setting up the content of ideological and political courses scientifically and reasonably}

At present stage, problems in the ideological and political courses teaching in Chinese higher schools are as follows: firstly, the content forms of the ideological and political courses are not novel enough and difficult to meet the development requirements of the era; secondly, the disciplinary knowledge tends to be systematized, and emphasis is placed on theoretical knowledge rather than practices; thirdly, repetition often exists in the knowledge content between ideological and political courses and other disciplines. These phenomena not only will affect the enthusiasms of students in learning ideological and political courses, but also may affect the effectiveness of the courses. Thus, scientifically and reasonably must be considered in the discipline setting. Not only repetition in ideological and political disciplinary content needs to be prevented, but also repetition between ideological and political courses and other courses should be avoided, so as to ensure the stability and effectiveness of the discipline; in addition, scientific methods should be adopted to design the teaching content, the main content of ideological and political courses teaching should be clarified, part of the content should not be overly simplified, and special subject teaching should be carried out if condition allowed. Besides, the combination of theory with reality should be realized, specific issues should be dealt with through theories, the "advancing with the times"of ideological and political teaching materials should be highlighted, and the teaching materials should be modified regularly to include new content.

\section{Expanding faculty}

The construction of faculty is one of the main contents of the construction of ideological and 
political courses. As college teachers are main bodies of teaching ideological and political discipline, it is necessary to continuously improve their professional ability and ideological level, so as to strengthen the construction of ideological and political courses. In terms of ideology, expanding of the faculty should be strengthened and attached importance to, perfect teacher training program should be formulated, and outstanding teachers should be regularly arranged to communicate with teachers in other higher schools and to actively participate in academic seminars, thus learning from the teaching thoughts and teaching methods of advanced education staff and broadening horizons, which can help teachers in ideological and political education to improve their level of expertise and ideological moral level. In addition, organizing and carrying out collective activities can also expand faculty, such as organizing centralized training, teaching and research and lesson preparation.

The teachers should be ensured to communicate through collective activities, so as to achieve the purpose of coordinated development. Higher schools should increase fund input into the ideological and political courses, make corresponding investment in accordance with the plan and setting of the courses, and ensure the integrity of materials and facilities related to the courses, thus guaranteeing the normal progress of ideological and political courses teaching. It needs to be emphasized that the increase of fund input into ideological and political courses should be carried out step by step. Firstly, the input should be set as an independent project, and then as a content of the budget. In addition, higher schools should build perfect reward mechanism, and teachers with outstanding achievements should be given appropriate awards to improve their working enthusiasm and make them establish stronger work consciousness [1].

\section{Mastering the ideological and political problems that students attach importance}

In order to improve the effectiveness of ideological and political courses in higher schools, higher schools especially the teachers are required to fully master the students' learning condition, let students understand ideological and political issues that should be attached importance to, sum up the main problems of students' concern through the mastery of the basic situation of students, and then adopt a variety of new teaching methods, thus improving the students' enthusiasms, stimulating their creativity, and creating a favorable atmosphere for ideological and political courses in higher schools. Ideological and political teachers must actively adopt various teaching methods in the teaching process, for example, their own teaching content can be organically combined with the exchanges with students; the knowledge content should not only be explained according to chapters, but also be combined with special lectures; they should be good at the application of multimedia technology to present the teaching content, should be concentrated and arouse students' learning enthusiasms; they can combine classroom teaching with life reality. No matter what kind of teaching means is adopted, it is aimed at the needs of students and to improve students' logicality in thinking about problems, to make students establish correct outlook on life, world outlook and values and to improve students' ideological and political feelings, the fundamental aim is to ensure that students can reasonably apply the ideological and political theories into social practices, and achieve mastery through a comprehensive study.

\section{Establishing and perfecting the teaching evaluation system}

Teaching evaluation system mainly includes two aspects, one is the evaluation system aimed at teachers constructed by higher schools, and the other is the evaluation system aimed at students constructed by teachers. In order to ensure the effectiveness of ideological and political courses, the evaluation system aimed at teachers constructed by higher schools should be established and perfected, and in the process of constructing the system, higher schools should take into full consideration the teaching body and teaching situation, and make comparisons with other higher schools with similar characteristics. In addition, adequate consideration should be given to work tasks and class hour subsidies of ideological and political teachers, so as to improve working enthusiasms of the teachers, and strengthen the effectiveness of ideological and political courses. 
For the construction of evaluation system aimed at students constructed by teachers, first the idea of exam should be innovated, which involves both the innovation of exam values and that of exam subject thoughts. In terms of exam values, the ability of students should be focused on and examined to see whether their overall quality and creativity are improved in the learning of ideological and political courses; in terms of innovation of the exam subject thoughts, it is necessary to set students' personality development as the premise, arouse the enthusiasms of students, and improve their creativity [2].

\section{Encouraging students to actively participate in social practice activities}

In ideological and political courses teaching, carrying out targeted social practice teaching activities is not only the core content of ideological and political course teaching reform, but also the main channel to improve teaching efficiency. Firstly, students' extra-curricular time should be made full use of, and they should be guided to actively participate in ideological and political teaching activities, such as free service and work-study program; secondly, students should be encouraged to organize and launch social practice activities, such as social practice and investigation and "three supports and one assistance", and the local ideological and political education resources should be fully utilized, so that students can be fitted into the social practice activities, which is conducive to giving full play to consciousness of students, and ensuring the effectiveness of the ideological and political courses teaching.

\section{Conclusions}

To sum up, in order to improve the effectiveness of ideological and political courses teaching in higher schools, teachers should be required to constantly analyze the characteristics of the ideological and political courses, adopt diversified teaching methods according to the psychological characteristics, thoughts and actions of modern college students, correctly apply the methods into the teaching process of ideological and political courses, and fully mobilize the enthusiasms of college students in learning ideological and political courses, thus promoting the integral development of college students.

\section{Acknowledgement}

In this paper, the research was sponsored by the Foundation project of philosophy and social science 2015R037 in Shaanxi province: Studying under the perspective of Silk Road to the Belt and Road of rural doctors team development in Shaanxi Province

\section{References}

[1] Zhang Zheng. A brief analysis of how to enhance the effectiveness of ideological and political courses teaching in higher schools in the new period [J]. Reform \& Opening, 2011 (12): 185.

[2] Ren Weiwei, Qin Shuang. How to enhance the effectiveness of ideological and political courses teaching in higher schools in the new period [J]. The Guide of Science \& Education (midmonth edition), 2016 (05): 75-76. 